\title{
Correction: Analysis of the Olive Fruit Fly Bactrocera oleae Transcriptome and Phylogenetic Classification of the Major Detoxification Gene Families
}

The PLOS ONE Staff

The fourth author's name is spelled incorrectly. The correct name is: Antonios Chrysargyris. The correct citation is: Pavlidi N, Dermauw W, Rombauts S, Chrysargyris A, Van Leeuwen T, Vontas J, et al. (2013) Analysis of the Olive Fruit Fly Bactrocera oleae Transcriptome and Phylogenetic Classification of the Major Detoxification Gene Families. PLoS ONE 8(6): e66533. 10. 1371/journal.pone.0066533

\section{Reference}

1. Pavlidi N, Dermauw W, Rombauts S, Chrisargiris A, Van Leeuwen T, Vontas J, et al. (2013) Analysis of the Olive Fruit Fly Bactrocera oleae Transcriptome and Phylogenetic Classification of the Major Detoxification Gene Families. PLoS ONE 8(6): e66533. doi: 10.1371/journal.pone.0066533 PMID: 23824998

\section{Open ACCEss}

Citation: The PLOS ONE Staff (2015) Correction: Analysis of the Olive Fruit Fly Bactrocera oleae Transcriptome and Phylogenetic Classification of the Major Detoxification Gene Families. PLoS ONE 10(5): e0128056. doi:10.1371/journal.pone.0128056

Published: May 8, 2015

Copyright: @ 2015 The PLOS ONE Staff. This is an open access article distributed under the terms of the Creative Commons Attribution License, which permits unrestricted use, distribution, and reproduction in any medium, provided the original author and source are credited. 